\title{
PENGARUH PENDIDIKAN KESEHATAN TERHADAP PENGETAHUAN IBU TENTANG PERAWATAN PAYUDARA PADA IBU POST PARTUM DI RSIA PURI BETIK HATI PROVINSI LAMPUNG TAHUN 2018
}

\author{
Eka Trismiyana'), Rahma Elliya2) \\ ${ }^{1}$ Dosen Akademi Keperawatan Universitas Malahayati Bandar Lampung \\ Email: ekatrismiyana@gmail.com \\ 2 Dosen Program Studi IImu Keperawatan Universitas Malahayati Bandar Lampung \\ Email: bundaauliyusri@yahoo.co.id
}

\begin{abstract}
Background Basic Health Research in 2013 showed breastfeeding in Indonesia is concerned, the percentage of babies exclusively breastfed until 6 months only $15.3 \%$. With a target of $85 \%$ coverage taget. This is due to public awareness in promoting breastfeeding is still relatively low. The results of observations made on 5 mothers at Puribetik Hati Hospital, found 3 mothers with knowledge about breast care less good, it is indicated by the existence of mastitis / breast swelling, hot and red palpable breasts, and 2 mothers with good knowledge, mother do warm water compresses, in areas slightly swollen.

PurposeKnowing that effect of health education on mother knowledge about breast treatment postpartum at Puri Betik Hati Hospital Province of Lampung 2018.

Methods This research type is quantitative, with the design of this study is Quasi Experimental with one group pretest-postes design approach, population number and sample of 17 respondents, sample technique used purpose sampling. The research will be conducted at Puri Betik Hati Hospital2018, with questionnaire research instrument and statistic test using test-test.

ResultFinding average knowledge before giving counseling that is Mean 11.18 Std. Dev 1.912 S. Eror 0.464 (9-15), after counseling Mean 18.29 Std. Dev 1.213 S. Eror 0.294 (16-20). Statistical test results t-tes obtained p-value 0.000 .

Conclusion There waseffect of health education on mother knowledge about breast treatment postpartum atPuri Betik Hati Hospital Province of Lampung 2018. It is suggestion to management hospital can add information about breast care in patient so hopefully get increase breastfeeding with good frequency in post partum so the baby can get enough milk.
\end{abstract}

Keywords: Counseling, mother's knowledge, breast care

\section{ABSTRAK}

Latar Belakang: Riset Kesehatan Dasar tahun 2013 menunjukkan pemberian ASI di Indonesia saat ini memprihatinkan, presentase bayi yang menyusu eksklusif sampai dengan 6 bulan hanya 15,3\%. Dengan target cakupan $85 \%$ taget. Hal ini disebabkan kesadaran masyarakat dalam mendorong peningkatan pemberian ASI masih relative rendah. Hasil observasi yang dilakukan terhadap 5 orang ibu bersalin di RSIA Puribetik Hati, didapat 3 ibu dengan pengetahuan tentang perawatan payudara kurang baik, hal tersebut ditunjukan dengan terdapatnya mastitis/ pembengkakan payudara, payudara teraba panas dan merah, dan 2 ibu dengan pengetahuan baik, ibu melakukan kompres air hangat, pada daerah yang sedikit mengalami bengkak.

Tujuan:Diketahui pengaruh pendidikan kesehatan terhadap pengetahuan ibu tentang perawatan payudara pada ibu postpartum di RSIA Puri Betik Hati Provinsi Lampung Tahun 2018.

Metode:Jenis penelitian ini adalah kuantitatif, dengan desain penelitian ini adalah Quasi Eksperimental dengan pendekatan one group pretes-postes design, jumlah populasi dan sampel sebanyak 17 responden, teknik sampel menggunakan accidental sampling. Penelitian akan dilakukan di RSIA Puri Betik Hati Tahun 2018, dengan instrument penelitian kuisioner dan uji statistic menggunakan ujit-tes.

HasilDidapatkanrata-rata pengetahuan sebelum diberikan penyuluhan yaitu Mean 11.18 Std. Dev 1.912 S. Eror 0.464 (9-15), setelah penyuluhan Mean 18.29 Std. Dev 1.213 S. Eror 0.294 (16-20). Hasil uji statistik ttes didapat nilai $p$-value 0.000 .

KesimpulanTerdapat pengaruh pendidikan kesehatan terhadap pengetahuan ibu tentang perawatan payudara pada ibu pos partum di RSIA Puri Betik Hati Provinsi Lampung Tahun 2018. Disarankan kepada 
manajemen rumah sakitdapat menambah informasi mengenai perawatan payudara pada pasien sehingga diharapkan dapatkan meningkatkan ASI dengan frekuensi yang baik pada ibu post partum sehingga bayi dapat mendapatkan ASI yang cukup.

Kata Kunci: Penyuluhan, pengetahuan ibu, perawatan payudara

\section{PENDAHULUAN}

Menyusui dan memberikan ASI secara eksklusif memang sangat bermanfaat, namun belum terlaksana sepenuhnya, diperkirakan $85 \%$ ibu-ibu di dunia tidak memberikan ASI secara optimal. Data mengenai pemberian ASI pada bayi di beberapa Negara pada tahun 2011-2012 diperoleh bahwa bayi di Amerika mendapatkan ASI eksklusif justru meningkat $60-70 \%$. Pada Tahun 2013 cakupan ASI Eksklusif di India saja sudah mencapai $45 \%$, di Philippines $37 \%$, di Vietnam $27 \%$ dan di Myanmar 24\% (Rusli, 2008).

Dari Riset Kesehatan Dasar (RISKESDAS) tahun 2013 menunjukkan pemberian ASI di Indonesia saat ini memprihatinkan, presentase bayi yang menyusu eksklusif sampai dengan 6 bulan hanya $15,3 \%$. Dengan target cakupan $85 \%$ taget. Hal ini disebabkan karena ketidaktahuan tentang perawatan payudara dan kesadaran masyarakat dalam mendorong peningkatan pemberian ASI masih relative rendah (Departemen Kesehatan, 2015).

Pemberian ASI pada bayi usia 0-1 tahun mempunyai arti yang sangat penting, terutama menyangkut pemenuhan kebutuhan gizi dan zat lain pembentuk kekebalan tubuh terhadap penyakit (Sutomo\& Anggraini,2010). Pemberian ASI secara eksklusif di usia 0-6 bulan dipandang sangat strategis, karena pada usia tersebut kondisi bayi masih labil dan rentan terhadap berbagai penyakit. Cakupan bayi mendapat ASI eksklusif di provinsi lampung tahun sebesar $57.70 \%$ dimana angka ini masih di bawah target yang diharapkan yaity 80\%(Profil Kesehatan Provinsi Lampung, 2015).

Berdasarkan cakupan per kabupaten Bandar Lampung masuk 5 besar dalam kategori cakupan dibawah rata-rata $57.70 \%$, terendah berada pada Kab. Mesuji 43.91\%, selanjutnya Kab. Lampung Utara 48.27\%, Kab. Tulang Bawang Barat 50.13\%, Kab. Lampung Timur 50.43\% dan terakhir Bandar Lampung $51.99 \%$ (Dinas Kesehatan Provinsi Lampung, 2015).

Persalinan merupakan keluarnya hasil konsepsi selama kurang lebih 9 bulan dengan menggunakan persalinan normal ataupun dengan bantuan, seperti operasi SC. Angka kejadian seksio sesarea di Indonesia menurut data survey nasional pada tahun 2007 adalah 921.000 dari 4.039 .000 persalinan atau sekitar $22,8 \%$ dari seluruh persalinan (Departemen Kesehatan Republik Indonesia, 2011). Seksio sesarea adalah suatu persalinan buatan dimana janin dilahirkan melalui suatu insisi pada dinding depan perut dan dinding rahim dengan syarat rahim dalam keadaan utuh serta berat janin diatas 500 gram (Sukarni\& Margareth, 2013).

Sedangkan persalinan normal atau spontan menurut survey nasional pada tahun 2011 adalah 6.456 .780 dari 7.329 .000 dari persalinan atau sekitar $79.2 \%$ dari jumlah persalinan yang terjadi di Indonesia (Depkes RI, 2011). Pada primigravida persalinan merupakan pengalaman pertama dalam masa kehidupannya, sehingga dibutuhkan informasi terkait tentang persalinan dan pemberian ASI pada bayi baru lahir.

Beberapa ibu post partum primigravida akan mengalami sedikit kebingungan, ketika melakukan kegiatan memberikan ASI pada bayinya, selain itu ibu bersalin akan mengalami masalah kelancaran ASI pada minggu pertama, maka sangat perlu diberikan pendidkan kesehatan mengenai post partum breast care untuk meningkatkan pengetahuan ibu (Puspita, 2015).

Post partumbreast care pada ibu nifas merupakan perawatan payudara yang dilakukan ibu pasca nifas unuk memperlancar sirkulasi darah dan mencegah tersumbatnya saluran air susu. Pelaksanaan perawatan post partum breast care dimulai sedini mungkin yaitu 1-2 hari setelah bayi lahir dan dilakukan 2 kali sehari (Wulandari,2012). Dampak negative timbul jika tidak dilakukan post natal breast care antara lain : putting susu mengendap, produksi ASI terbatas, payudara bengkak bendungan ASI (Prawirohardjo, 2008)

Penelitian Rutiani\& Fitriana(2017)dengan judul "Gambaran Bendungan ASI Pada Ibu Nifas Dengan Seksio Sesarea Berdasarkan Karakteristik Di Rumah Sakit Sariningsih Bandung Tahun 2017". Hasil penelitian menunjukkan sebanyak 47 responden (58\%) memiliki pengetahuan baik dan 34 responden $(42 \%)$ memiliki pengetahuan kurang baik tentang perawatan payudara.

Berdasarkan data Presurvey yang dilakukan di RSIA Puri Betik Hati Provinsi Lampung, dengan total kunjungan pada tahun 2017 sebanyak 194 
orang ibu bersalin, didapat data bahwa persalinan pada ibu primigravida, dan berdasarkan hasil observasi yang dilakukan terhadap 5 orang ibu bersalin primigravida didapat 3 ibu dengan pengetahuan tentang perawatan payudara kurang baik, hal tersebut ditunjukan dengan terdapatnya mastitis/ pembengkakan payudara, payudara teraba panas dan merah, dan 2 ibu dengan pengetahuan baik, ibu melakukan kompres air hangat, pada daerah yang sedikit mengalami bengkak, ibu juga melakukan pijatan dengan perlahan kearah aerola, sehingga ASI dapat keluar sedikit demi sedikit, dan mengurangi nyeri, akibat bendungan ASI. Penyebab rendahnya pemberian ASI salah satunya di sebabkan karena ketidaktahuan tentang perawatan payudara sehingga peneliti mengambil judul tentang penting untuk melakukan penkes terkait perawatan payudara yang menyebabkan angka kejadian pemberian ASI masih rendah

Berdasarkan fenomena diatas, maka peneliti tertarik melakukan penelitian dengan judul Pengaruh Pendidikan Kesehatan Terhadap Pengetahuan lbu Tentang Perawatan Payudara Pada Ibu Post Partum di RSIA Puri Betik Hati Provinsi Lampung Tahun 2018.

\section{METODOLOGI PENELITIAN}

Penelitian ini adalah kuantitatif, dengan desain penelitian ini adalah Quasi Eksperimental dengan pendekatan one group pretes-postes design, teknik sampel menggunakan accidental sampling. , dengan instrument penelitian kuisioner dan uji statistic menggunakan ujit-tes.

Populasi adalah keseluruhan dari objek penelitian. Pemilihan populasi dan sampel merupakan salah satu faktor yang mempengaruhi berhasil atau tidaknya suatu penelitian (Notoadmodjo,2010). Populasi dalam penelitian ini adalah seluruh ibu post partum primigravida di RSIA Puri Betik Hati Tahun 2017, dengan jumlah 194 ibu bersalin baik SC atau normal selama 1

tahun, dan rata-rata kejadian persalinan sebanyak 15-17 kunjungan/ bulan.

Sampel adalah sebagian objek yang diteliti dan dianggap mewakili populasi (Notoatmodjo,2010). Penentuan jumlah sampel dalam penelitian ini berdasarkan konsep dan penerapan metodelogi penelitian eksperimen yaitu jumlah sampel dengan rata-rata / bulan sebanyak 15-17 kunjungan/ bulan. Menurut Dempsey (2012) sampel penelitian pada jenis penelitian eksperimen, dapat dilakukan dengan menggunakan 17 responden.

HASIL

Karakteristik Responden

Tabel 1

Karakteristik Responden Berdasarkan Usia, Pendidikan Di Ruang Kebidanan RSIA Puri Betik Hati Provinsi Lampung Tahun 2018

\begin{tabular}{lcc}
\hline \multicolumn{1}{c}{ Variabel } & Jumlah & $\begin{array}{c}\text { Persentase } \\
(100 \%)\end{array}$ \\
\hline Usia & & \\
22-30 Tahun & 11 & 64.7 \\
$\geq 30$ Tahun & 6 & 35.3 \\
\hline \multicolumn{1}{c}{ Total } & 17 & 100 \\
\hline Pendidikan & & \\
SMP & 5 & 29.4 \\
SMA & 8 & 47.1 \\
D3/S1 & 4 & 23.5 \\
\hline \multicolumn{1}{c}{ Total } & 17 & 100 \\
\hline
\end{tabular}

Berdasarkan tabel 1 dapat dilihat karakteristik responden berdasarkan usia terbanyak adalah 22-30 tahun 11 responden (64.7\%), dan pendidikan terbanyak adalah SMA 8 responden $(47.1 \%)$.

\section{Analisa Univariat}

Dari tabel2 dibawah dapat diketahui bahwa rata-rata pengetahuan ibu dengan Mean 11.18 Std. Dev 1.912 S. Eror 0.464 nilai benar kuisioner pengetahuan min-max 9-15.

Tabel 2

Rata-RataPengetahuan Pada Ibu Post Partum Primigravida Sebelum Diberi Pendidikan Kesehatan Tentang Perawatan Payudara Di Ruang Kebidanan RSIA Puri Betik Hati Provinsi Lampung Tahun 2018

\begin{tabular}{cccccc}
\hline Variabel & $\mathrm{N}$ & Mean & St. Dev & S.Eror & Min-Max \\
\hline Pengetahuan sebelum penyuluhan & 17 & 11.18 & 1.912 & 0.464 & $9-15$ \\
\hline
\end{tabular}

Dari tabel 3 dibawah dapat diketahui bahwa rata-rata pengetahuan ibu dengan Mean 18.29 Std.
Dev 1.213 S. Eror 0.294 nilai benar kuisioner pengetahuan min-max 16-20. 
Tabel 3

Rata-RataPengetahuan Pada Ibu Post Partum Primigravida Sesudah Diberi Pendidikan Kesehatan Tentang Perawatan Payudara Di Ruang Kebidanan RSIA Puri Betik Hati Provinsi Lampung Tahun 2018

\begin{tabular}{cccccc}
\hline Variabel & $\mathrm{N}$ & Mean & St. Dev & S.Eror & Min-Max \\
\hline Pengetahuan sesudah penyuluhan & 17 & 18.29 & 1.213 & 0.294 & $16-20$ \\
\hline
\end{tabular}

Tabel 4

Uji Normalitas

\begin{tabular}{ccccc}
\hline Variabel & N & Mean & Std. Deviation & $P$-Value \\
\hline Pengetahuan Sebelum Penyuluhan & 17 & 11.18 & 1.912 & 0.732 \\
Pengetahuan Sesudah Penyuluhan & 17 & 18.29 & 0.249 & 0.569 \\
\hline
\end{tabular}

Uji normalitas adalah uji prasyarat sebelum dilakukannya uji perbedaan atau pengaruh (compare means). Pada penelitian ini peneliti menggunakan uji normalitas kosmologrov smirnov dengan ketentuan : Jika nilai $p$-value $>$ dari 0.05 maka distribusi normal Jika nilai $p$-value $<$ dari 0.05 maka distribusi tidak normal, $p$-value pada penelitian ini didapat 0.732 yang artinya lebih besar dari 0.05 maka data berdistribusi normal, dan selanjutnya dapat dilakukan uji pengaruh.

\section{Analisis Bivariat}

Dari table5 terlihat bahwa rata-rata pengetahuan sebelum dan sesudah diberikan penyuluhan yaitu Mean $11.18 \mathrm{Std}$. Dev $1.912 \mathrm{~S}$. Eror 0.464 nilai benar kuisioner pengetahuan minmax 9-15., mengalami perubahan rata-rata pengetahuan ibu setelah diberi penyuluhan dengan Mean 18.29 Std. Dev 1.213 S. Eror 0.294 nilai benar kuisioner pengetahuan min-max 16-20. Dengan selisih mean -7.118, Std. Deviasi 2.288 dan S. Eror0.555 Hasil uji statistik $t$-tes didapat nilai $p$-value $0.000(<0.05)$ yang artinya terdapat Pengaruh Pendidikan Kesehatan Terhadap Pengetahuan lbu Tentang Perawatan Payudara Pada Ibu Post Partum Primigravida Di RSIA Puri Betik Hati Provinsi Lampung Tahun 2018.

Tabel 5

Pengaruh Pendidikan Kesehatan Terhadap Pengetahuan Ibu Tentang Perawatan Payudara Pada lbu Post Partum Primigravida Di RSIA Puri Betik Hati Provinsi Lampung Tahun 2018

\begin{tabular}{cccccc}
\hline Variabel & $N$ & Mean & Std. Dev & SE & $P$-Value \\
Pengetahuan sebelum penyuluhan & 17 & 11.18 & 1.912 & 0.464 & 0.000 \\
Pengetahuan sesudah penyuluhan & 17 & 18.29 & 1.213 & 0.294 & \\
\hline
\end{tabular}

\section{PEMBAHASAN}

\section{Analisis Univariat}

Rata-RataPengetahuan Pada lbu Post Partum Primigravida Sebelum Diberi Pendidikan Kesehatan Tentang Perawatan Payudara Di Ruang Kebidanan RSIA Puri Betik Hati Provinsi Lampung Tahun 2018

Berdasarkan hasil analisa pada penelitian yang telah dilakukan pada 17 responden dapat diketahui bahwa rata-rata pengetahuan sebelum dan sesudah diberikan penyuluhan yaitu Mean 11.18 Std. Dev 1.912 S. Eror 0.464 nilai benar kuisioner pengetahuan min-max 9-15.

Menurut teori Notoatmodjo (2010) pengetahuan merupakan hasil dari "Tahu" dan ini terjadi setelah orang melakukan penginderaan terhadap suatu objek tertentu. Penginderaan terjadi melalui panca indra manusia, yaitu: indra penglihatan, pendengaran, penciuman, rasa dan raba (Wardani,2013) Sebagian besar pengetahuan manusia diperoleh melalui mata dan telinga, yaitu proses melihat dan mendengar. Selain itu melalui mata dan telinga yaitu proses melihat dan mendengar, selanjutnya proses pengalaman dan proses belajar dalam pendidikan formal maupun informal.

Sejalan dengan penelitian yang dilakukan oleh Aisyahwa (2013) dengan judul "Pengaruh penyuluhan tentang perawatan payudara terhadap pengetahuan ibu bersalin di Klinik Bersalin Sucenti Pinarwat Bungur Nganjuk Jawa Tengah". Didapat nilai mean 17.890 SD 7.154 SE 0.887.

Pada penelitian ini terdapat 17 responden yang memiliki pengetahuan kurang baik sebanyak 9 responden, dan 8 responden dengan pengetahuan 
baik. Menurut peneliti tingginya pendidikan tidak mempengaruhi hasil pengetahuan ibu, pengetahuan dipengaruhi oleh banyaknya informasi yang masuk atau diterima, pada penelitian ini ratarata responden berpendidikan SMA dan dengan pekerjaan terbanyak yaitu ibu rumah tangga, yang kurang berkomunikasi, dan pada pendidikan S1/ D3 kemungkinan pendidikan yang disandang bukanlah pendidikan kesehatan, sehingga informasi yang didapat juga masih kurang, kesibukan ibu dan tingkat pemahaman ibu dalam mengingat informasi.

Menurut peneliti kurangnya pengetahuan ibu dalam mendapat informasi baik dari internet atau penyuluhuan oleh kader kesehatan. Selain faktor pengetahuan, pendidikan serta pekerjaaan juga mempengaruhi dalam pengetahuan ibu tentang perawatan payudara, pendidikan tinggi tidak selalu memiliki hasil pengetahuan yang baik, seperti pada penelitian ini pada pendidikan SMA-S1 yang tergolong pendidikan tinggi rata-rata hanya mendapat skor 45-75\%, sedangkan pada pendidikan rendah SMP terdapat 5 responden dengan skor $45-50 \%$ yang artinya pengetahuan responden baik, jadi dapat disimpulkan jika pengetahaun tidak serta merta dipengaruhi oleh pendidikan, melainkan dari informasi yang diterima saat berkomunikasi dengan sesama ibu rumah tangga atau saat bekerja, seperti komunitas berdagang, dan perkantoran.

Rata-RataPengetahuan Pada lbu Post Partum Primigravida Sesudah Diberi Pendidikan Kesehatan Tentang Perawatan Payudara Di Ruang Kebidanan RSIA Puri Betik Hati Provinsi Lampung Tahun 2018

Berdasarkan hasil penelitian yang dilakukan pada 17 responden menunjukan bahwa rata-rata pengetahuan ibu setelah diberi penyuluhan dengan Mean 18.29 Std. Dev 1.213 S. Eror 0.294 nilai benar kuisioner pengetahuan min-max 16-20.

MenurutMardiantari(2012) pengetahuan merupakan domain yang penting dalam membentuk tindakan seseorang (overt behavior). Proses kognitif meliputi ingatan, pikiran, persepsi, simbol-simbol penalaran dan pemecahan persoalan. Penegertian dalam kamus besar Bahasa Indonesia (2015), diartikan segala sesuatu yang diketahui atau segala sesuatu yang berkenaan dengan hal mata pelajaran. Kategori pengetahuan meliputi kemampuan untuk mengatakan kembali dari ingatan hal-hal khusus dan umum, metode dan proses atau mengingat suatu pola, susunan, gejala atau peristiwa.

Sejalan dengan penelitian yang dilakukan oleh Aisyahwa (2013) dengan judul "Pengaruh penyuluhan tentang perawatan payudara terhadap pengetahuan ibu bersalin di Klinik Bersalin Sucenti Pinarwat Bungur Nganjuk Jawa Tengah". Setelah diberi penyuluhan didapat nilai mean 18.347 SD 5.671 SE 0.653.

Pada penelitian ini hasil pengetahuan setelah diberi penyuluhan seluruhnya mengalami peningkatan 17 responden dengan pengetahuan baik, 17 responden keseluruhan mengalami peningkatan nilai benar dari 3-6 skor, pada penelitian ini seluruh usia responden rata-rata 2230 tahun, Menurut peneliti, semakin matang usia seseorang akan mempengaruhi pengalamannya, baik dalam memperoleh pengetahaun, informasi. Berdasarkan pengalaman seseorang dapat saling bertukar pikiran atau sharing, sehingga dapat meningkatkan pengetahuan, seperti pengetahuan dan manfaat tentang perawatan payudara.

Pada penelitian ini terlihat memiliki kesamaan dengan penelitian yang dilakukan oleh Aisyahwa (2013) dengan judul "Pengaruh penyuluhan tentang perawatan payudara terhadap pengetahuan ibu bersalin di Klinik Bersalin Sucenti Pinarwat Bungur Nganjuk Jawa Tengah". Didapat nilai mean 17.890 SD 7.154 SE 0.887. dan setelah penyuluhan Setelah diberi penyuluhan didapat nilai mean 18.347 SD 5.671 SE 0.653, yang artinya terdapat peningkatan pengetahuan ibu sebelum dan setelah diberi penyuluhan.

\section{Analisa Bivariat}

Pengaruh Pendidikan Kesehatan Terhadap Pengetahuan Ibu Tentang Perawatan Payudara Pada Ibu Post Partum Primigravida Di RSIA Puri Betik Hati Provinsi Lampung Tahun 2018

Berdasarkan hasil penelitian didapat hasil uji statistik $t$-tes didapat nilai $p$-value $0.000 \quad(<0.05)$ yang artinya terdapat Pengaruh Pendidikan Kesehatan Terhadap Pengetahuan lbu Tentang Perawatan Payudara Pada lbu Post Partum Primigravida Di RSIA Puri Betik Hati Provinsi Lampung Tahun 2018.

Sejalan dengan penelitian oleh Aisyahwa (2013) dengan judul "Pengaruh penyuluhan tentang perawatan payudara terhadap pengetahuan ibu bersalin di Klinik Bersalin Sucenti Pinarwat Bungur Nganjuk Jawa Tengah". Didapat nilai mean 17.890 SD 7.154 SE 0.887. dan setelah penyuluhan Setelah diberi penyuluhan didapat nilai mean 18.347 SD 5.671 SE 0.653, dengan nilai p-value $0.000<0.05$ ) yang artinya terdapat Pengaruh penyuluhan tentang perawatan payudara terhadap pengetahuan ibu bersalin di Klinik Bersalin Sucenti Pinarwat Bungur Nganjuk Jawa Tengah.

Pengetahuan dapat dipengaruhi dari banyaknya sumber informasi yang didapat, seperti 
Pengetahuan responden dipengaruhi oleh tingkat pendidikan seseorang, yang ditempuhnya, semakin tinggi tingkat pendidikan, maka semakin banyak informasi yang diterima oleh responden tersebut, lingkungan tempat tinggal dan faktor pekerjaan juga dapat mempengaruhi informasi yang didapat (Scholichah,2012).

Selain pendidikan pekerjaan berhubungan dengan sosial ekonomi seseorang. Semakin tinggi tingkat sosial ekonomi seseorang akan menambah tingkat pengetahuan. Lingkungan sosial akan mendukung tingginya pengetahuan seseorang, sedangkan ekonomi berkaitan dengan pendidikan. Apabila status ekonomi baik tingkat pendidikan juga akan tinggi dan diiringi oleh peningkatan pengetahuan (Mawaddah\& Hardinsyah,2008).

Menurut peneliti kurangnya pengetahuan pada ibu tentang perawatan payudara sangat berpengaruh terhadap kelancaran ASI ibu pasca bersalin. Pemberian penyuluhan perawatan payudara sangatlah tepat dilakukan pada ibu bersalin yang memiliki masalah kelancaran, dan akan lebih efektif lagi pada ibu sebelum bersalin. Dari hasil analisis dapat diketahui bahwa pemberian perlakuan memberikan dampak yang positif bagi pasien. Hal ini diketahui dari adanya perawatan payudara pada ibu post partum signifikan pada pasien. Dampak positif berupa adanya peningkatan pengetahuan ibu dari nilai rata-rata yang meningkat, sirkulasi darah lancar, payudara bersih. Menurut peneliti, pasien yang telah mendapat perlakuan dengan menggunakan perawatan payudara mempunyai rasa ketenangan, nyaman dan peningkatan pengetahuan setelah dilakukan penyuluhan terkait perawatan payudara dan perhatian yang lebih baik dalam mengikuti pemberian ASI yang eksklusif setelah bersalin.

\section{SIMPULAN}

Hasil uji statistik $t$-tes didapat nilai $p$-value $0.000 \quad(<0.05)$ yang artinya terdapat Pengaruh Pendidikan Kesehatan Terhadap Pengetahuan Ibu Tentang Perawatan Payudara Pada lbu Post Partum Primigravida Di RSIA Puri Betik Hati Provinsi Lampung Tahun 2018.

\section{SARAN}

Hasil penelitian dapat memberikan informasi dan wacana kepustakaan mengenai perawatan payudara bagi ibu hamil dan menyusui, dengan menggunakan perawatan payudara yang baik dqan benar saat sebelum bersalin, memiliki efek bagi kelancaran ASI, memberikan sumbangan data mengenai manfaat pemberian penyuluhan bagi peningkatan pengetahuan ibu akan manfaat dari perawatan payudara. Dapat menambah informasi mengenai perawatan payudara pada pasien sehingga diharapkan dapatkan meningkatkan ASI dengan frekuensi yang baik pada ibu post partum sehingga bayi dapat mendapatkan ASI yang cukup, kebersihan payudara terjaga, kenyamanan dalam memberikan ASI, mengurangi tingkat nyeri payudara saat menyusui, mengurangi pembengkakan payudara,sumber referensi dan dasar untuk melakukan penelitian selanjutnya mengenai perawatan payudara pada ibu hamil, serta diharapkan bafgi peneliti terdahulu untuk dapat mengganti variabel terkait lainnya yang dapat meningkatkan pengetahuan ibu terkait kelancaran ASI saat setelah bersalin.

\section{DAFTAR PUSTAKA}

Departemen Kesehatan Republik Indonesia. (2011). Profil data kesehatan Indonesia 2011.

Dinas Kesehatan Provinsi Lampung .(2015). Profil Kesehatan Provinsi Lampung tahun 2015

Kamus Besar Bahasa Indonesia. (2015). Kamus versi online. Daring (Dalam Jaringan). Melalui< http://kbbi. web. id/s[14/05/13].

Mardiantari, D. (2012). Hubungan Antara Tingkat Pengetahuan lbu Tentang $\mathrm{Kb}$ Suntik Dengan Sikap Dalam Memilih Kb Suntik 3 Bulanan Di Desa Besole, Kecamatan Bayan, Kabupaten Purworejo. JURNAL KOMUNIKASI KESEHATAN (Edisi 5), 3(2).

Mawaddah, N., \& Hardinsyah, H. (2008). Pengetahuan, Sikap, Dan Praktek Gizi Serta Tingkat Konsumsi lbu Hamil Di Kelurahan Keramat Jati Dan Kelurahan Ragunan Propinsi Dki Jakarta. Jurnal Gizi Dan Pangan, 3(1), 30-42.

Notoatmodjo, S. (2008). Metodologi Penelitian Cetakan 4. Jakarta: Rineka Cipta.

Notoatmodjo, S. (2010). Metodologi penelitian kesehatan.

Notoatmodjo, S. (2012). Promosi kesehatan dan perilaku kesehatan. Jakarta: Rineka Cipta, 45-62.

Prawirohardjo, S. (2008). Fisiologi Kehamilan, Persalinan, Nifas, dan Bayi Baru Lahir. IImu Kebidanan. 4th ed. Jakarta: PT Bina Pustaka Sarwono Prawirohardjo, p174-187.

Puspita, S. (2015). Asuhan Kebidanan Komprehensif Kehamilan Trimester lii, Persalinan, Bayi Baru Lahir, Nifas Dan Masa Antara (Keluarga Berencana Suntik 3 Bulan) Pada Ny. Y Umur 29 Tahun G2p1a0 Di Puskesmas 1 Wangon 
Banyumas (Doctoral Dissertation, Universitas Muhammadiyah Purwokerto).

Riyanto, A. Budiman.(2013). Kapita Selekta Kuisioner: Pengetahuan dan Sikap dalam Penelitian Kesehatan. Jakarta: Salemba Medika.

Rusli, H. U. (2008). Inisiasi menyusui dini plus ASI eksklusif. Puspa Swara.

Rutiani, C. E. A., \& Fitriana, L. A. (2017). Gambaran Bendungan ASI Pada Ibu Nifas Dengan Seksio Sesarea Berdasarkan Karakteristik Di Rumah Sakit Sariningsih Bandung. Jurnal Pendidikan Keperawatan Indonesia, 2(2), 146-155.

Scholichah, N. (2012). Hubungan perawatan payudara pada ibu postpartum dengan kelancaran pengeluaran ASI di desa karang duren kecamatan tengaran kabupaten semarang. Jurnal Komunikasi Kesehatan (Edisi 3), 2(02).

Sukarni, I., \& Margareth, Z. H. (2013). Kehamilan, persalinan, dan nifas. Yogyakarta: Nuha Medika.

Sutomo, B., \& Anggraini, D. Y. (2010). Menu Sehat Alami Untuk Batita \& Balita. DeMedia.

Wardani, R. (2013). Faktor-Faktor Yang Mempengaruhi Perilaku Ibu Dalam Memilih Makanan Sehari-Hari Dalam Keluarga Di Rt 25 Rw 09 Lingkungan Tirtoudan Kelurahan Tosaren. Eduhealth, $3(2)$.

Wulandari, V. (2012). Hubungan Antara Tingkat Pengetahuan Ibu Primigravida Dengan Perilaku Perawatan Payudara Pada Saat Hamil Di Wilayah Kerja Puskesmas Karangdowo Klaten (Doctoral dissertation, Universitas Muhammadiyah Surakrta). 